\title{
Correction: Amsterdam wrist rules: a clinical decision aid
}

\author{
Abdelali Bentohami ${ }^{1 \dagger}$, Monique MJ Walenkamp ${ }^{1 \dagger}$, Annelie Slaar ${ }^{4}$, M Suzan H Beerekamp ${ }^{1}$, Joris AH de Groot ${ }^{2}$, \\ Eva M Verhoog ${ }^{3}$, L Cara Jager ${ }^{3}$, Mario Maas ${ }^{4}$, Taco S Bijlsma ${ }^{5}$, Bart A van Dijkman ${ }^{6}$, Niels WL Schep ${ }^{1 *}$ \\ and J C Goslings ${ }^{1}$
}

The name of one of the authors of this manuscript [1] was misspelled. The correct name is: J. Carel Goslings. We regret any inconvenience this error has caused.

\section{Competing interests}

All authors have no competing interests.

Authors' contribution

All authors have read and approved the final manuscript.

\section{Author details}

${ }^{1}$ Trauma Unit, Department of Surgery, Academic Medical Center, University of Amsterdam, P.O. Box 22660, 1100 DD, Amsterdam, The Netherlands. ${ }^{2}$ Department of Clinical Epidemiology, University Medical Center, Utrecht, Huispost Str. 6.131, P.O. BOX 85500, 3508 GA, Utrecht, The Netherlands.

${ }^{3}$ Department of Emergency Medicine, Academic Medical Center, University of Amsterdam, P.O. Box 22660, 1100 DD, Amsterdam, The Netherlands. ${ }^{4}$ Department of Radiology, Academic Medical Center, University of Amsterdam, P.O. Box 22660, 1100 DD, Amsterdam, The Netherlands. ${ }^{5}$ Department of Surgery-Traumatology, Spaarne Hospital, Spaarnepoort 1, 2134 TM, Hoofddorp, The Netherlands. ${ }^{6}$ Department of SurgeryTraumatology, Flevo Hospital, Hospitaalweg 1, 1315 RA, Almere,

The Netherlands.

Received: 7 March 2013 Accepted: 7 March 2013

Published: 2 April 2013

\section{Reference}

1. Bentohami A, Walenkamp MM, Slaar A, Beerekamp MS, de Groot JA, Verhoog EM, et al: Amsterdam wrist rules: a clinical decision aid. BMC Musculoskelet Disord 2011, 12:238. Oct 17.

\footnotetext{
*Correspondence: n.w.schep@amc.nl

${ }^{\dagger}$ Equal contributors

'Trauma Unit, Department of Surgery, Academic Medical Center, University of Amsterdam, P.O. Box 22660, 1100 DD, Amsterdam, The Netherlands
} Full list of author information is available at the end of the article

\section{Submit your next manuscript to BioMed Central and take full advantage of:}

- Convenient online submission

- Thorough peer review

- No space constraints or color figure charges

- Immediate publication on acceptance

- Inclusion in PubMed, CAS, Scopus and Google Scholar

- Research which is freely available for redistribution

Submit your manuscript at www.biomedcentral.com/submit

\section{() Biomed Central}

\section{() Biomed Central}

